Primljen / Received: 8.10.2018.

Ispravljen / Corrected: 24.3.2019.

Prihvaćen / Accepted: 8.5.2019.

Dostupno online / Available online: 10.6.2020.

\section{Testing and interpreting permeability of asphalt mixes}

Authors:

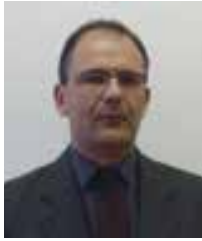

Assoc.Prof. Csaba Tóth, PhD. CE

Budapest University of Technology and Economics Faculty of Civil Engineering

toth.csaba@epito.bme.hu

Correspondence author

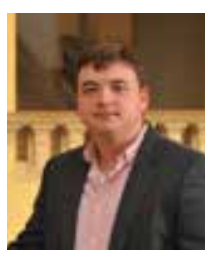

Assist.Prof. Zoltán Soós, PhD. CE

Budapest University of Technology and Economics Faculty of Civil Engineering

soos.zoltan@epito.bme.hu

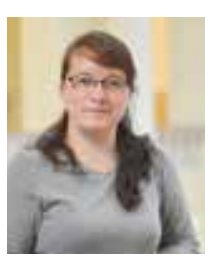

Assist.Prof. Zsuzsanna Igazvölgyi, PhD. CE Budapest University of Technology and Economics Faculty of Civil Engineering igazvölgyi.zsuzsanna@epito.bme.hu

\section{Csaba Tóth, Zoltán Soós, Zsuzsanna Igazvölgyi}

\section{Testing and interpreting permeability of asphalt mixes}

This paper presents a field study showing the distribution of air voids in asphalt layers, and the potential effect of water on pavement performance. The paper also discusses the applicability of the European test method and equipment for assessing permeability of asphalt layers. A series of laboratory permeability tests were conducted on in-situ core samples and laboratory samples. It was found that mixes with smaller particle sizes, the air void content results in lower permeability compared to mixes with larger particle sizes.

Key words:

asphalt permeability, pavement moisture content, air voids content, Computed Tomography (CT)

Prethodno priopćenje

Csaba Tóth, Zoltán Soós, Zsuzsanna Igazvölgyi

\section{Ispitivanje i ocjena propusnosti asfaltnih mješavina}

Ovaj rad prikazuje terensko istraživanje kojim je pokazana raspodjela šupljina u asfaltnim slojevima i potencijalni utjecaj vode na svojstva kolnika. Razmatra je primjenjivost europske metode ispitivanja i opreme za ocjenu propusnosti asfaltnih slojeva. Proveden je niz laboratorijskih ispitivanja propusnosti na uzorcima iz ugrađenog asfaltnog sloja i na laboratorijskim uzorcima. Utvrđeno je da u slučaju mješavina s manjom veličinom zrna, udio šupljina rezultira nižom propusnosti u usporedbi s mješavinama s većim česticama.

Ključne riječi:

propusnost asfalta, vlažnost kolnika, udio šupljina, računalna tomografija (CT)

Vorherige Mitteilung

Csaba Tóth, Zoltán Soós, Zsuzsanna Igazvölgyi

\section{Überprüfung und Bewertung der Durchlässigkeit von Asphaltmischungen}

In dieser Abhandlung wird die Feldstudie dargelegt, mit welcher die Verteilung von Hohlräumen in den Asphaltschichten sowie die möglichen Auswirkungen des Wassers auf die Fahrbahnmerkmale dargestellt werden. Betrachtet wird die Anwendbarkeit der europäischen Prüfmethode und der -ausrüstung auf die Bewertung der Durchlässigkeit der Asphaltschichten. Durchgeführt wurde eine Reihe von Laboruntersuchungen der Durchlässigkeit an Proben aus eingebauter Asphaltschicht, wie auch an Laborproben. Festgestellt wurde, dass im Falle von Mischungen mit kleineren Körnern der Anteil der Hohlräume zu einer niedrigeren Durchlässigkeit im Vergleich zu Mischungen mit größeren Partikeln führt.

Schlüsselwörter:

Durchlässigkeit des Asphalts, Fahrbahnfeuchtigkeit, Anteil an Hohlräumen, Computertomografie (CT) 


\section{Introduction}

The presence of water in road pavement layers is evident for unbound granular layers such as subgrades and subbase layers; however, its presence in and between bound layers, especially asphalt layers, is still considered a novelty to the wider professional community, despite numerous publications have been available in this field since the 1960s [1].

Several cases of water-induced damage to asphalt layers have been published in international and national literature $[2,3]$. Since the 1970s, a number of case studies have also depicted clear relations between the compaction rate and interlayer bonding of asphalt layers and the presence and movement of water within and between asphalt layers, respectively [4-7]. Despite such findings, no specifications have been made in a number of countries, including Hungary, about permeability of asphalt layers. Such specifications normally require only testing of the air voids content of the placed layer(s). The authors have encountered several cases of water permeability issues within asphalt layers and asphalt pavements when conducting research and consulting works at the Asphalt and Railway Laboratory of the Budapest University of Technology and Economics. The asset owner of a major Hungarian motorway contacted the Laboratory to analyse possible causes of pavement failure, involving symptoms related to water movement within asphalt layer(s). The issue was investigated based on international literature, and a permeability testing device, conforming to the relevant European Standard [8], was acquired. Main findings relying on these simple test methods and computed tomography (CT) are presented in the paper, and attempts are made to establish further research goals for additional assessment of such problems.

\section{Test plan}

Ground-penetrating radar (GPR) measurements were carried out on a total of five selected sections of the motorway. According to the test plan, in-situ core samples were extracted from all traffic lanes and the emergency lane (two samples from each lane), equalling to a total of 30 samples. Almost all samples showed the presence of water at first sight as parts of the samples were wet after several hours or being on the surface, showing a relatively higher void content - filled with water from the wet cutting process as shown in Figure 1 as an example.

According to international literature, permeability of asphalt pavements is primarily related to air void content (rate of compaction) in the placed layers; accordingly, the test plan consisted of permeability measurements and determination of air void content. For the first time in Hungary, computed tomography (CT) was also applied as an experimental technique.

\section{Asphalt permeability tests}

Several test methods for determining permeability of laboratory prepared asphalt samples and placed layers are currently available. The results of field tests are convincing as, in these cases, the permeability of pavement cracks is also taken into account, in addition to material permeability of pavement layers. Moreover, in this case, the permeability of the whole pavement is tested i.e. the water capable of reaching the subgrade is inferred [9-12].

Laboratory tests according to the European standard [8] consist of a water column of constant height in a cone making the permeation of water through the sample possible. Figure 2 shows the test setup for two standard methods, the vertical permeability, where the water permeates into and out of the sample on the horizontal plane, and the horizontal permeability measurement, where the water permeates into the sample on the horizontal plane, but permeates out at the vertical cylinder. In both cases, the water column is kept at constant height resulting in constant water pressure, and the mass of water exfiltrating the sample is measured over time. Permeability is given as calculated in eqn. (1) and (2).

$$
\begin{aligned}
& k_{v}=\frac{4 \cdot \frac{m}{t} \cdot 10^{-6} \cdot l}{h \cdot \pi \cdot D^{2}} \\
& k_{h}=\frac{\frac{m}{t} \cdot 10^{-6} \cdot l}{(H+P+0,5 l) \cdot(\pi \cdot D \cdot l)}
\end{aligned}
$$

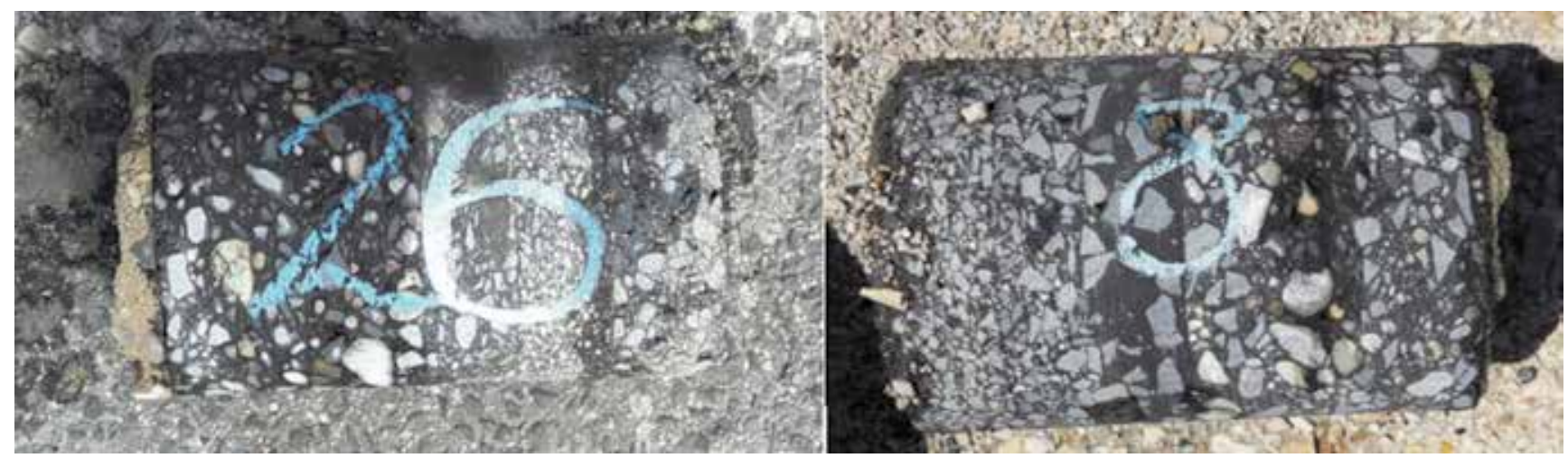

Figure 1. Examples of wet core samples 

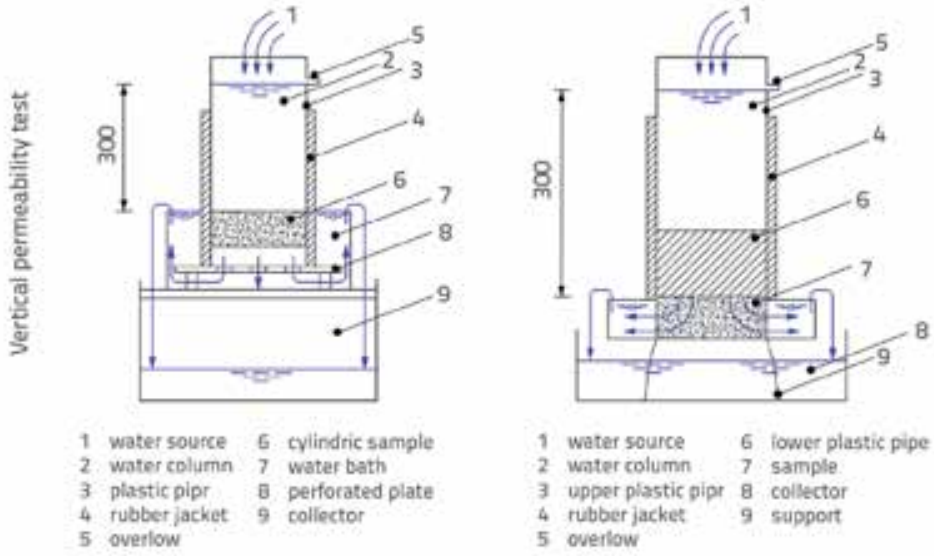

Figure 2. Test method for horizontal and vertical permeability

where:

$\mathrm{k}_{\mathrm{v}}$ and $\mathrm{k}_{\mathrm{h}}$ - vertical and horizontal permeability [m/s]

$\mathrm{m} \quad-$ mass of permeated water $[\mathrm{g}]$

$\mathrm{t} \quad-$ test time [s]

I - thickness of sample [m]

$\mathrm{H}+\mathrm{P} \quad$ - height of water column plus the sample [m]

D - specimen diameter [m]

h - height of water column [m].

The air void content of the samples was determined using the standard test method EN 12697-8. The test method is assumed to be commonly known and will not be discussed here.

\section{Computed tomography}

Computed tomography (CT) can be used to analyse composition of a given material, via assessment of frequently made sectional images, leading to a whole new level of material analysis [13]. These images are created using X-ray measurements from different angles, detecting the rays through the samples and processing the data with special software (see Figure 3).
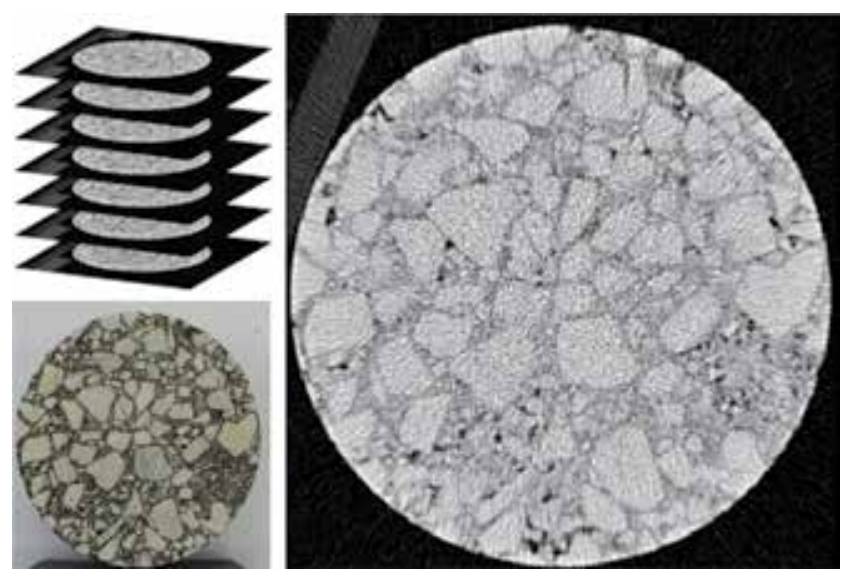

Figure 3. Essence of a CT measurement and computed picture of a core sample
There can be several cases for using CT in the research of asphalt mixes. Most of the research at hand focuses on methods for evaluating microstructure of asphalt specimens via various procedures [13-16]. There are also papers that investigate the asphalt microstructure obtained via CT and the estimated mechanical or structural performance $[17,18]$ to complete the well established fundamental description of mix behaviour [19, 20].

Using this technology, the proportions of aggregate, binder, filler, and air voids within a given sample can be estimated with some precision, which is mainly dependant on the CT device and the algorithms used for data assessment. CT tests were conducted on the samples with the focus on the distribution of the air voids with depth. The results are shown in Figure 4, where the distance between the slices is 1,5 $\mathrm{mm}$. The interlayers are also shown in the figure.

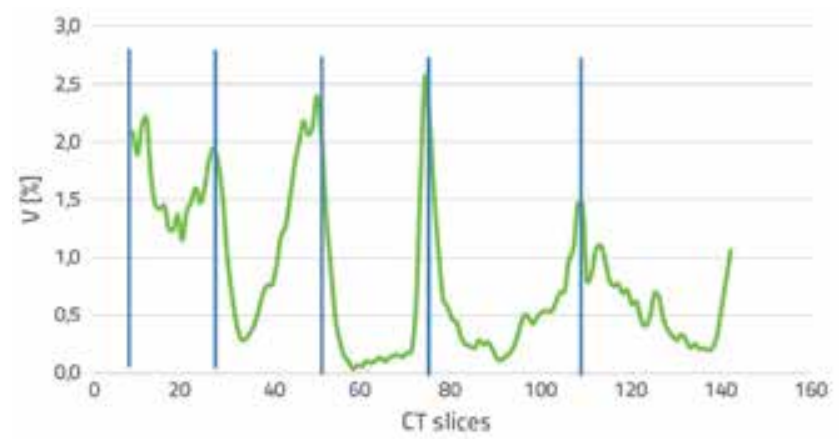

Figure 4. Distribution of air voids in a core sample

As shown in Figure 4, there is a significant increment in air void content at all interlayers. The observed increase in air voids at the interlayers cannot be detected via normal control tests for the two main reasons:

- The cores are normally cut at the interlayer to separate layers, resulting in approximately $5 \mathrm{~mm}$ reduction of the total thickness of the interlayer.

- Each layer is tested separately, i.e. the air void content is averaged with the rest of the sample, which is of higher weight

Field observations and literature show that there is a high possibility of water movement at the interlayer; this observation is in line with the sharp increase of air void content as shown in Figure 4. This phenomenon is caused by the following occurrences:

- In most cases where asphalt layers are laid on a cold surface and the bottom part of the asphalt mat is radically cooled,

- Due to the lower temperature of the mat at the bottom part, compaction is compromised at this level,

- On a milled (texturized) existing layer the macrotexture of the milled surface and the aggregate size of the new layer are not compatible, resulting in a similar influence. 


\section{Test results}

As shown in a number of previous research papers, there is a clear correlation between the air void content and permeability. However, the permeability of asphalt samples is not only affected by the air void content, maximum particle size, sample dimensions, and measurement method, but also by hydraulic characteristics of water $[21,22]$. These findings are quite similar to the ones presented in the research on permeability of cement concrete $[23,24]$. There are also research findings suggesting correlation between the normalised air void content and permeability. Permeability of different magnitudes can be assessed according to Table 1 [25].

Table 1. Suggested permeability categories for asphalt materials

\begin{tabular}{|c|c|c|c|}
\hline Cat. & $\begin{array}{c}\text { Permeability } \\
{[\mathrm{m} / \mathrm{s}]}\end{array}$ & $\begin{array}{c}\text { Air void content } \\
{[\%]}\end{array}$ & Description \\
\hline A1 & $0.01-0.1$ & $2.5-3.7$ & very low permeability \\
\hline A2 & $0.1-1$ & $3.7-5.6$ & low permeability \\
\hline B & $1-10$ & $5.6-8.5$ & medium permeability \\
\hline C & $10-100$ & $8.5-13$ & high permeability \\
\hline D & $100-1000$ & $13-20$ & almost permeable \\
\hline E & $1000-10000$ & $>20$ & permeable (drain asphalt) \\
\hline
\end{tabular}

Design and threshold values are determined on the technological basis. Layers showing the air void content indicated in Table 2 are assumed to be impermeable, [26]. The construction tolerance is $+3 \%$, although a given layer may be accepted within an additional $+2 \%$ air void content at a discounted price. A given pavement layer is rejected at the air void content given in the last row.

As previous research indicates, the correlation between the air void content and permeability shows a third-degree polynomial relation in the form of $K=A \cdot \exp (B \cdot V)$. Parameters $A$ and $B$ were determined using Solver, for air void-permeability of samples, for each particle size separately. The coefficient of determination was found to be high for all individual cases, and ranges from 0.85 to as much as 0.98 , as shown in Figures 5 , 6 , and 7. Parameters and regression coefficients are shown in Table 3.

A strong correlation was established between the permeability and air void content and, at that, the aggregate particle size was also taken into consideration. The results are based on 11,9 , and 24 test results, respectively, as some samples were damaged during processing or coring.

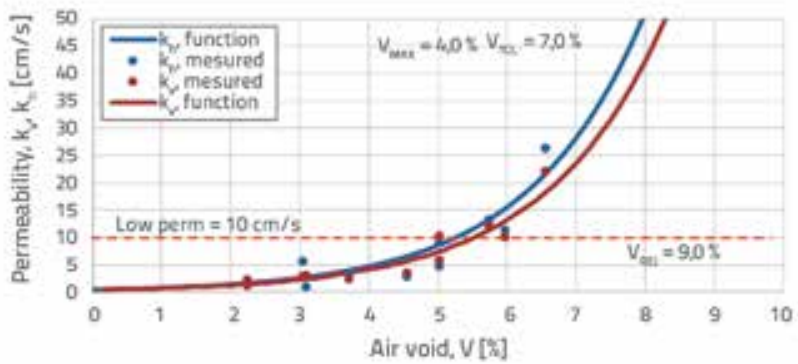

Figure 5. Measured and calculated permeability, AC11 layer

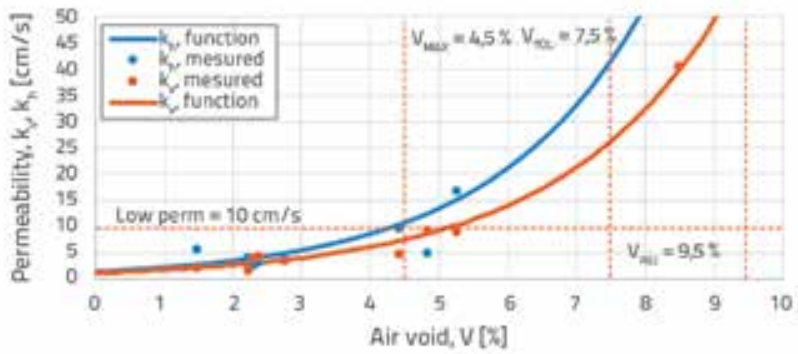

Figure 6. Measured and calculated permeability, SMA8 layer

Table 2. Air voids for design, tolerance, reduced quality and rejected cases

\begin{tabular}{|c|c|c|c|c|c|c|c|c|c|}
\hline \multirow{2}{*}{\multicolumn{2}{|c|}{ Asphalt mix }} & \multicolumn{3}{|c|}{ Wearing courses } & \multicolumn{3}{|c|}{ Binder courses } & \multicolumn{2}{|c|}{ Base courses } \\
\hline & & SMA 8 & SMA 11 & $\begin{array}{l}\text { AC11 } \\
\text { AC16 }\end{array}$ & AC11 & AC16 & AC22 & AC16 & $\begin{array}{l}\text { AC22 } \\
\text { AC32 }\end{array}$ \\
\hline \multirow{2}{*}{ Design } & $\mathrm{V}_{\mathrm{MIN}}$ & \multicolumn{2}{|c|}{$2.0 \%$} & $2.5 \%$ & \multicolumn{3}{|c|}{$3.0 \%$} & \multicolumn{2}{|c|}{$3.0 \%$} \\
\hline & $V_{\text {MAX }}$ & $4.0 \%$ & $4.5 \%$ & $4.5 \%$ & $4.5 \%$ & $5.0 \%$ & $5.5 \%$ & $5.0 \%$ & $6.0 \%$ \\
\hline \multicolumn{2}{|c|}{ Tolerance, $\mathrm{V}_{\text {TOL }}$} & \multicolumn{8}{|c|}{$\mathrm{V}_{\max }+3.0 \%$} \\
\hline \multicolumn{2}{|c|}{ Reduced, $V_{\text {RED }}$} & \multicolumn{8}{|c|}{$\mathrm{V}_{\mathrm{TOL}}+2.0 \%$} \\
\hline \multicolumn{2}{|c|}{ Rejected, $\mathrm{V}_{\mathrm{REJ}}$} & $9.0 \%$ & $9.5 \%$ & $9.5 \%$ & $9.5 \%$ & $10.0 \%$ & $10.5 \%$ & $10.0 \%$ & $11.0 \%$ \\
\hline
\end{tabular}

Table 3. Coefficient of determination in analysed cases

\begin{tabular}{|c|c|c|c|c|c|c|}
\hline \multirow{2}{*}{ Asphalt mix } & \multicolumn{3}{|c|}{ Vertical permeability } & \multicolumn{3}{c|}{ Horizontal permeability } \\
\cline { 2 - 7 } & A & B & $\mathbf{R}^{2}$ & A & B & $\mathbf{R}^{\mathbf{2}}$ \\
\hline SMA8 $(n=11)$ & $4.37 \cdot 10^{-8}$ & 0.59 & 0.86 & $4.24 \cdot 10^{-8}$ & 0.58 & 0.90 \\
\hline AC11 $(n=9)$ & $1.42 \cdot 10^{-7}$ & 0.45 & 0.97 & $1.15 \cdot 10^{-7}$ & 0.42 & 0.98 \\
\hline AC22 $(n=24)$ & $1.74 \cdot 10^{-7}$ & 0.41 & 0.91 & $1.47 \cdot 10^{-7}$ & 0.37 & 0.85 \\
\hline
\end{tabular}




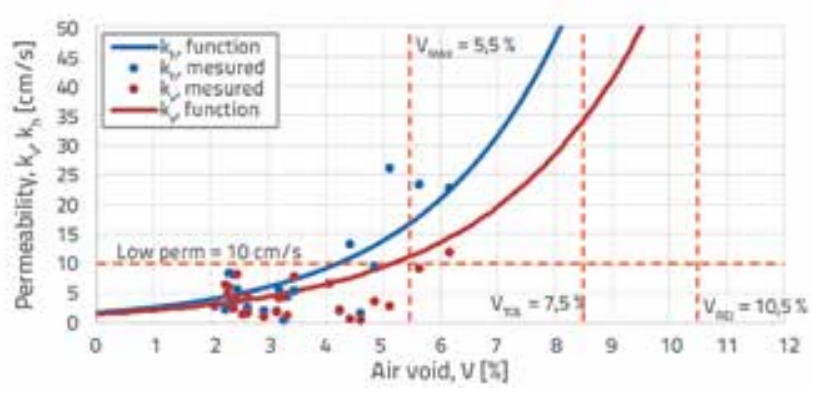

Figure 7. Measured and calculated permeability, AC22 layer

When meeting current specification limits with regard to in situ air void contents, the permeability of the finished asphalt layer may be heavily compromised across a variety of asphalt mix types.

The average, minimum, and maximum values (see Figure 4), as well as the median value, were calculated for the CT-derived air void content. Figures 8 and 9 show these air void content values plotted against the values obtained using the EN 126978 standard method after the CT measurements.

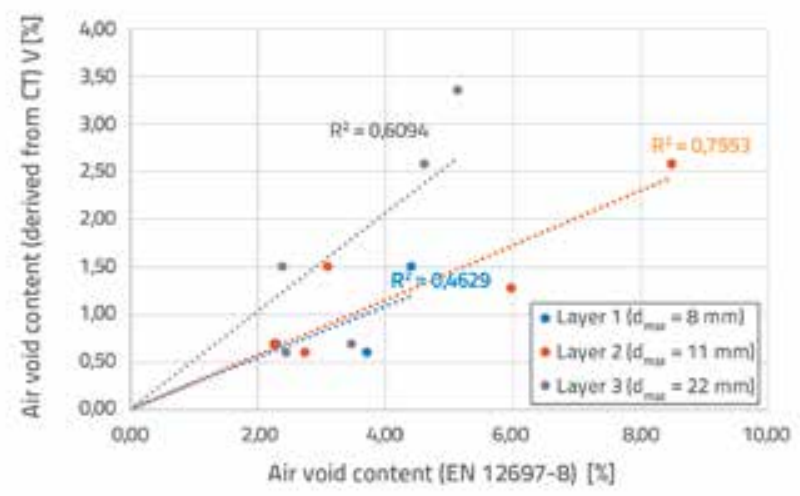

Figure 8. Air voids estimated based on CT (average values) as a function of air voids according to European standard

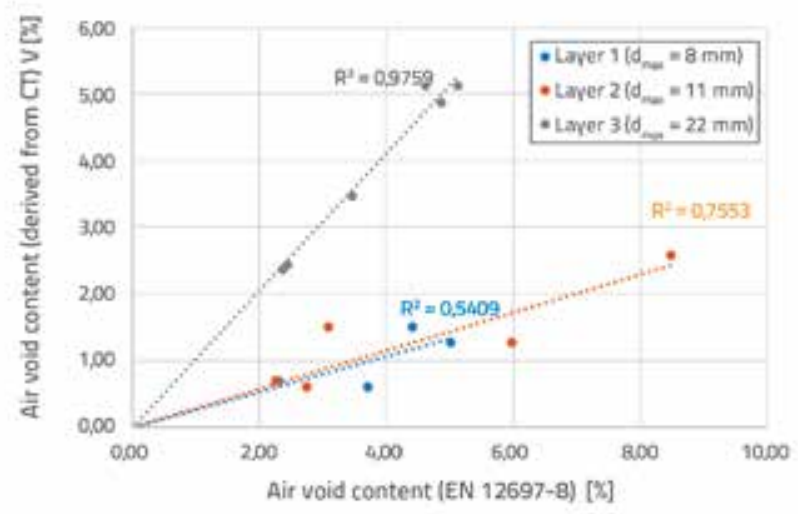

Figure 9. Air voids estimated based on CT (median values) as a function of air voids according to European standard
As can be seen, low-to-average correlation values were obtained for linear regression with an intersection at 0,0. Trends show that in cases of layer 3 (were the maximum aggregate size is $22 \mathrm{~mm}$ ) the values are close to the $1: 1$ ratio, with a relatively high regression coefficient, at both average and median values, which may suggest that one or both methods are more accurate at larger aggregate sizes. This conclusion is also supported by the trends of layer 1 (maximum aggregate size of $11 \mathrm{~mm}$ ), having the lowest nominal aggregate size and the lowest level of correlation between the air void contents. A distinction between aggregate sizes of the samples should be made to determine the possibility of conversion between the methods [27].

\section{Conclusions}

An investigation was carried out on core samples extracted from a major Hungarian motorway, and it revealed failures due to the presence of water in asphalt pavement. Where the performance of the pavement structure was compromised and water detected by the GPR, cores were extracted and tested using the European test method for permeability.

Core sample test results show a clear correlation between the air void content and the horizontal and vertical permeability of the samples; the findings are in line with relevant international experience.

The results showed that horizontal permeability is always higher than vertical permeability, which shows a difference in test method, and indicates that the two methods should be distinguished from one another. It was found that in case of mixes with smaller particle sizes, the air void content results in lower permeability compared to mixes with bigger particle sizes. This also indicates that results should be analysed considering not only the air void content, but also the particle size distribution. Compaction technology obviously has a high impact on the permeability, but it is not the only parameter $[28,29]$.

With regard to theair void content derived from CT measurements and obtained using the EN 12697-8 standardised method, it can be concluded that there is a need for further research, in which not only a logical correlation but also a mathematical conversion should be established. In the latter case the nominal aggregate size must be taken into account [30, 31].

Based on the air void content versus permeability, asphalt layers meeting air voids limits according to the specifications may be in fact permeable, which may lead to a variety of pavement failure types and deterioration of lower pavement layers. Based on the results presented in this paper, a well-established relation may be determined between permeability and air void content. This could result in incorporation of layer waterproofness in the specifications, which is presently poorly addressed. The introduction of permeability limits in relevant specifications would require establishing precision of the test method, which is currently unknown. 


\section{REFERENCES}

[1] Gáspár, L.: Management aspects of road pavement rehabilitation, GRAĐEVINAR, 69 (2017) 1, pp. 31-40, https://doi.org/10.14256/ JCE.1629.2016

[2] TRL, The Movement of Water in Roads, London, 2006.

[3] Reid, J., Crabb, G., Temporal, J., Clark, M.: A study of water movement in road pavements, London: TRL, 2006.

[4] Dawson, A.: Water movement in road pavements, University of Nottingham: Proceedings of the Second Symposium on Unbound Aggregates in Roads, pp. 7-12, 1985.

[5] Morris, P., Gray, W.: Moisture conditions under roads in the Australian environment, Australian Road Research Board: Research Report ARR No. 69, 1976.

[6] Ožbolt, M., Rukavina, T., Stančerić, I.: Possibilities of using GPR in the analysis of pavement structures, GRAEEVINAR, 61 (2009) 3, pp. 251-259.

[7] Sekulić, D., Strineka, A., Putrić Brkić, J.: Determining thickness of asphalt and concrete layers by non-destructive method, GRAĐEVINAR, 63 (2011) 2, pp. 143-149.

[8] EN 12697-19: Bituminous mixtures. Test methods for hot mix asphalt. Permeability of specimen, European Standard, 2012.

[9] Ridgeway, H.: Infiltration of Water Through the Pavement Surface, Washington: Transportation Research Record, 1976.

[10] Brown, E., Cooley, L.: NCAT report 01-03 - Developing Critical Field Permeability and Pavement Density Values for Coarse-Graded Superpave Pavements, Journal of the Transportation Research Board, 2014, http://dx.doi.org/10.3141/1761-06.

[11] Cooley, L.: Permeability of Superpave Mixtures: Evaluation of Field Permeameters, Auburn University, National Centre for Asphalt Technology, 1999.

[12] Cygas, D., Laurinavicius, A., Vorobjovas, V., Kleiziene, R., Vaitkus, A.: Research of asphalt layer bonding in Lithuanian pavement structures, GRAĐEVINAR, 64 (2012) 11, pp. 915-921.

[13] Chen, Z., Hainian W., Zhanping, Y., Xu, Y.: Compaction characteristics of asphalt mixture with different gradation type through Superpave Gyratory Compaction and X-Ray CT Scanning, Construction and Building Materials 129 (2016), pp. 243-255.

[14] Zavrtanik, N., Ljubič, A., Turk, G.: Statistical deviations in the analysis of asphalt mix properties, GRAĐEVINAR, 67 (2015) 12, pp. 1199-1206, https://doi.org/10.14256/JCE.1176.2014

[15] Wistuba, M.P., Westerhoff, J., Moon, K.H., Falchetto, L.A.C.: Untersuchung der Mikrostruktur von Asphalt mitunterschiedlichen Anteilen Ausbauasphalt mittels digitaler Bildauswertung, Straße und Autobahn, 69 (2017) 2, pp. 87-96.

[16] Tashman, L., Masad, E., D’Angelo, J., Bukowski, J., Harman, T.: X-ray Tomography to Caracterize Air Void Distribution in Superpave Gyratory Compacted Specimens, International Journal of Pavement Engineering, 3 (2002) 1, pp. 19-28, https://doi. org/10.1080/10298430290029902a.

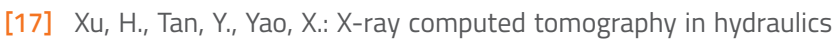
of asphalt mixtures: Procedure, accuracy, and application, Construction and Building Materials, 108 (2016), pp. 10-21.

[18] Magdy, S., Adil, A.M., Tighe, S.: A novel method for evaluating hot mix asphalt fatigue damage: X-ray computed tomography, Construction and Building Materials, 113 (2016), pp. 121-133.

[19] Gömze, A.L., Gömze, L.N.: Rheo-mechanical model for self-healing asphalt pavement, Journal OF Physics-Conference Series, 790 (2017) 1, pp. 9.

[20] Géber, R., Kocserha, I., Gömze L.A.: Influence of composition and grain size distribution on the properties of limestone and dolomite asphalt fillers, Materials Science Forum, 729 (2013), pp. 344-349.

[21] Ariza, P., Bjorn, B.: Evaluation of Water Flow Through Pavement Systems, NCHRP research report, 2002.

[22] COST 351: Water in Road Structures. Movement, Drainage and Effects, Nottingham: Springer, 2008.

[23] Mahalingam, R., Vaithiyalingam Mahalingam, S.: Analysis of pervious concrete properties, GRAĐEVINAR, 68 (2016) 6, pp. 493501, https://doi.org/10.14256/JCE.1434.2015

[24] Mrakovčić, S., Čeh, N., Jugovac, V.: Effect of aggregate grading on pervious concrete properties, GRAĐEVINAR, 66 (2014) 2, pp. 107113, https://doi.org/10.14256/JCE.977.2013

[25] Waters, T.: A study of water infiltration through asphalt road surface materials, International symposium on subdrainage in roadway pavements and subgrades, 1998.

[26] e-UT 06.03.21: Asphalt Pavement Courses for Road Constructions. Building Conditions And Quality Requirements, (Hungarian Standard), pp. 30, 2010.

[27] Mohiuddin, A., Tarefder, R.: Permeability and moisture damage characteristics of asphalt pavements, Proc. 51 Paving and Transportation Corporation at Albequerque, 2014.

[28] Mostafa, A., Amir, E.H., Bekheet, W., Abd El Halim, A.O., Easa, S.: Reducing susceptibility of flexible pavements to moisture induced damage through superior compaction technology, Proc. Canadian Society for Civil Engineering, $6^{\text {th }}$ Transportation Specialty Conference, 2005.

[29] Rueda, E.J., Caro, S., Caceido, B.: Influence of relative humidity and saturation degree in the mechanical properties of Hot Mix Asphalt (HMA) materials, Construction and Building Materials, 153 (2017), pp. 807-815

[30] Lublóy, É., Balázs, G.L., Barsi, Á.: CT analysis of core samples from fire-damaged concrete structures, Magazine of Concrete Research, 69 (2017) 15, pp. 802-810.

[31] Lublóy, É., Ambrus, D., Kapitány, K., Barsi Á.: Air void distribution of asphalts determined by computed tomography, Periodica Polytechnica Civil Engineering, 59 (2015) 4, pp. 503. 